\title{
Workplace risk factors for cancer in the German rubber industry: part 2. Mortality from non-respiratory cancers
}

Kurt Straif, Stephan K Weiland, Barbara Werner, Lloyd Chambless, Kenneth A Mundt, Ulrich Keil

\begin{abstract}
Objectives-To determine the mortality from non-respiratory cancers by work area among active and retired male workers of the German rubber industry.

Methods-A cohort of 11633 male German workers was followed up for mortality from 1 January 1981 to 31 December 1991. Cohort members were active $(n=7536)$ or retired $(n=4127)$ on 1 January 1981 and had been employed for at least one year in one of five study plants producing tyres or technical rubber goods. Work histories were reconstructed from routinely documented "cost centre codes" and classified into six categories: I preparation of materials; II production of technical rubber goods; III production of tyres; IV storage and dispatch; $V$ general service; VI others. Standardised mortality ratios (SMRs) and $95 \%$ confidence intervals $(95 \% \mathrm{CIs})$, controlling for age and calendar year and stratified by work area (employment in respective work area for at least one year) and time related variables (year of hire, lagged years of employment in work area) were calculated from national mortality rates as the reference.
\end{abstract}

Results-Significant increases in mortality were found for pharyngeal cancer in work area IV (three deaths, SMR 486, 95\% CI 101 to 1419), oesophageal cancer in work area III (11 deaths, SMR 227, 95\% CI 114 to 407), and leukaemia in work areas I (11 deaths, SMR 216; 95\% CI 108 to 387) and II (14 deaths, SMR 187; 95\% CI 102 to 213). Furthermore, increased SMRs were found for stomach cancer in work area I (22 deaths, SMR 134; 95\% CI 84 to 203), colon cancer in work area II (27 deaths, SMR 131, 95\% CI 86 to 191), prostatic cancer in work area V (27 deaths, SMR 152, 95\% CI 99 to 221), and bladder cancer in work areas IV (six deaths, SMR 253; 95\% CI 93 to 551) and $V$ (12 deaths, SMR 159, 95\% CI 82 to 279). Mortality from cancer of the liver or gall bladder, pancreas and kidney, and from lymphomas was not substantially increased in any of the work areas.

Conclusions-Mortality from cancer of several sites was associated with specific work areas. Some of these associations have been reported previously. Future analyses of our study will have to determine the role of specific exposures in the aetiology of these cancers.

(Occup Environ Med 1998;55:325-332)

Keywords: non-respiratory cancer mortality; rubber industry; work area risk factors

Previously, we reported general mortality patterns and cancer mortality by time related factors among male German rubber workers. ${ }^{1}$ More specifically, we presented workplace risk factors for respiratory cancers. ${ }^{2}$ In this paper we provide further results by work area for cancer sites that were selected on the basis of previous reports of an increased mortality among workers employed in the rubber industry. ${ }^{34}$ Also, we report results for mortality from pharyngeal cancer, because this cancer site was of primary concern when this cohort study was launched. Furthermore, two years after the updated evaluation by an International Agency for Research on Cancer (IARC) working group, ${ }^{4}$ a significant excess mortality from pharyngeal cancer was found among a large cohort of workers employed in the British rubber industry. ${ }^{5}$

\section{Methods and data analysis}

Cohort definition and follow up, assessment of vital status, and cause of death were described in a recent publication reporting on the general mortality experience of this cohort ${ }^{1}$ and were summarised in part I of this report, where we also presented exposure classification, data analysis, and general cohort characteristics. ${ }^{2}$ In both parts of this report, the mortality experience of the cohort was compared by standardised mortality ratio (SMR) analyses with the mortality of the general population. The SMRs were stratified by year of hire and cumulative duration of employment in specific work areas, implying that workers may seem to be in more than one work area. Based on specific assumptions about latency periods, duration of employment in specific work areas was lagged by five years for lymphomas and leukaemias, and 10 years for all other nonrespiratory cancers.

\section{Results}

In table 1 we give an overview of the results by work area for all 12 selected non-respiratory cancer sites. Mortalities from cancer of the liver and gall bladder (international classification of diseases ninth revision (ICD-9) 155-156), 
Table 1 Observed cancer deaths (obs) and SMRs (95\% CI) among male German rubber workers ( $n=11663)$ 1981-91 by cancer site and work area $(I-V I)^{\star}$

\begin{tabular}{|c|c|c|c|c|c|c|c|c|c|c|}
\hline \multirow[b]{2}{*}{ Cancer site } & \multirow[b]{2}{*}{$I C D-9$} & \multicolumn{3}{|c|}{ Preparation of materials (I) } & \multicolumn{3}{|c|}{ Technical rubber goods (II) } & \multicolumn{3}{|c|}{ Tyres (III) } \\
\hline & & Obs & $S M R$ & $(95 \% C I)$ & $O b s$ & $S M R$ & $(95 \% C I)$ & Obs & $S M R$ & $(95 \% C I)$ \\
\hline All causes & 000-999 & 742 & 118 & (110 to 127 ) & 1010 & 109 & (103 to 116$)$ & 694 & 105 & (97 to 113 ) \\
\hline All cancers & $140-208$ & 226 & 130 & (114 to 149$)$ & 290 & 112 & (100 to 126$)$ & 199 & 107 & (93 to 123 ) \\
\hline Pharynx & $146-149$ & 3 & 152 & (31 to 443$)$ & 5 & 144 & (47 to 336$)$ & 4 & 158 & (43 to 405 ) \\
\hline Oesophagus & 150 & 4 & 97 & (26 to 249 ) & 5 & 75 & ( 24 to 175 ) & 11 & 227 & (114 to 407$)$ \\
\hline Stomach & 151 & 22 & 134 & (84 to 203 ) & 26 & 108 & (71 to 159 ) & 18 & 105 & (62 to 165$)$ \\
\hline Colon & 153 & 13 & 93 & (49 to 158 ) & 27 & 131 & (86 to 191$)$ & 11 & 74 & (37 to 133 ) \\
\hline Rectum & 154 & 11 & 150 & (75 to 269 ) & 14 & 130 & (71 to 218 ) & 8 & 103 & (44 to 203 ) \\
\hline Liver or gall bladder & $155-156$ & 5 & 78 & (25 to 182$)$ & 4 & 42 & (11 to 108$)$ & 4 & 59 & (16 to 150$)$ \\
\hline Pancreas & 157 & 7 & 86 & (35 to 178 ) & 9 & 74 & (34 to 140 ) & 6 & 68 & ( 25 to 149 ) \\
\hline Prostate & 185 & 20 & 117 & (71 to 181 ) & 22 & 93 & (58 to 141 ) & 22 & 130 & (82 to 197$)$ \\
\hline Bladder & 188 & 9 & 124 & (56 to 235 ) & 11 & 106 & (53 to 190 ) & 7 & 94 & (38 to 194 ) \\
\hline Kidney & 189 & 7 & 119 & ( 48 to 246 ) & 9 & 101 & (46 to 192 ) & 3 & 46 & (9 to 136 ) \\
\hline Brain/CNS & $191-192$ & 2 & 80 & (10 to 290$)$ & 2 & 49 & (6 to 175$)$ & 3 & 100 & (21 to 293 ) \\
\hline Lymphoma & $200-203$ & 5 & 90 & (29 to 211 ) & 10 & 120 & (57 to 220 ) & 4 & 67 & (18 to 172$)$ \\
\hline Leukaemia & $204-208$ & 11 & 219 & (109 to 392$)$ & 14 & 189 & (103 to 317$)$ & 1 & 19 & \\
\hline
\end{tabular}

^Employment for at least 1 year in the respective work area (lagged, details see text).

Table 2 Cancer of the pharynx (ICD-146-149), observed deaths (obs) and SMRs (95\% CI) among male German rubber workers ( $n=11663$ ) 1981-91 by work area (I-VI), year of hire, and years of employment in work area (lagged by 10 years)

\begin{tabular}{|c|c|c|c|c|c|c|c|c|c|}
\hline & \multicolumn{3}{|c|}{ Preparation of materials (I) } & \multicolumn{3}{|c|}{ Technical rubber goods (II) } & \multicolumn{3}{|c|}{ Tyres (III) } \\
\hline & Obs & $S M R$ & $(95 \% C I)$ & Obs & $S M R$ & $(95 \% C I)$ & Obs & $S M R$ & $(95 \% C I)$ \\
\hline \multicolumn{10}{|l|}{ Year of hire: } \\
\hline$\geqslant 1960$ & 1 & 159 & & 4 & 375 & (102 to 960 ) & 2 & 254 & (31 to 915 ) \\
\hline $1950-9$ & 0 & 0 & & 1 & 54 & & 2 & 062 & (20 to 585$)$ \\
\hline$<1950$ & 2 & 362 & (44 to 1308 ) & 1 & 121 & & 0 & 0 & \\
\hline \multicolumn{10}{|c|}{ Years of employment in work area: } \\
\hline $1-9$ & 1 & 135 & & 3 & 250 & (52 to 730 ) & 3 & 446 & (92 to 1301 ) \\
\hline$\geqslant 10$ & 2 & 161 & (20 to 582$)$ & 2 & 88 & (11 to 318 ) & 1 & 54 & \\
\hline Total $(\geqslant 1 \mathrm{y})$ & 3 & 152 & (31 to 443 ) & 5 & 144 & (47 to 336$)$ & 4 & 158 & (43 to 405 ) \\
\hline
\end{tabular}

Table 3 Cancer of the oesophagus (ICD-150), observed deaths (obs) and SMRs (95\% CI) among male German rubber workers $(n=11663)$ 1981-91 by work area (I-VI), year of hire, and years of employment in work area (lagged by 10 years)

\begin{tabular}{|c|c|c|c|c|c|c|c|c|c|}
\hline & \multicolumn{3}{|c|}{ Preparation of materials (I) } & \multicolumn{3}{|c|}{ Technical rubber goods (II) } & \multicolumn{3}{|c|}{ Tyres (III) } \\
\hline & Obs & $S M R$ & $(95 \% C I)$ & Obs & $S M R$ & $(95 \% C I)$ & Obs & $S M R$ & $(95 \% C I)$ \\
\hline \multicolumn{10}{|l|}{ Year of hire: } \\
\hline$\geqslant 1960$ & 0 & 0 & & 2 & 123 & (15 to 443 ) & 2 & 172 & (21 to 621 ) \\
\hline $1950-9$ & 3 & 157 & ( 32 to 457 ) & 2 & 61 & (7 to 220$)$ & 5 & 230 & (75 to 536$)$ \\
\hline$<1950$ & 1 & 68 & & 1 & 47 & & 4 & 240 & (65 to 613 ) \\
\hline \multicolumn{10}{|c|}{ Years of employment in work area: } \\
\hline $1-9$ & 3 & 201 & (41 to 586 ) & 3 & 131 & (27 to 381 ) & 3 & 242 & (50 to 707 ) \\
\hline$\geqslant 10$ & 1 & 38 & & 2 & 46 & (6 to 166$)$ & 8 & 222 & (96 to 438 ) \\
\hline Total $(\geqslant 1 \mathrm{y})$ & 4 & 97 & (26 to 249 ) & 5 & 75 & (24 to 175$)$ & 11 & 227 & (114 to 407$)$ \\
\hline
\end{tabular}

Table 4 Cancer of the stomach (ICD-151), observed deaths (obs) and SMRs (95\% CI) among male German rubber workers ( $n=11663)$ 1981-91 by work area (I-VI), year of hire, and years of employment in work area (lagged by 10 years)

\begin{tabular}{|c|c|c|c|c|c|c|c|c|c|}
\hline & \multicolumn{3}{|c|}{ Preparation of materials (I) } & \multicolumn{3}{|c|}{ Technical rubber goods (II) } & \multicolumn{3}{|c|}{ Tyres (III) } \\
\hline & Obs & $S M R$ & $(95 \% C I)$ & Obs & $S M R$ & $(95 \% C I)$ & Obs & $S M R$ & $(95 \% C I)$ \\
\hline \multicolumn{10}{|l|}{ Year of hire: } \\
\hline$\geqslant 1960$ & 6 & 211 & (78 to 460 ) & 6 & 142 & (52 to 310 ) & 3 & 112 & (23 to 328$)$ \\
\hline $1950-9$ & 11 & 170 & (85 to 304 ) & 8 & 82 & ( 35 to 162 ) & 6 & 98 & (36 to 213 ) \\
\hline$<1950$ & 5 & 65 & (21 to 151 ) & 13 & 120 & (64 to 205 ) & 9 & 103 & (47 to 196 ) \\
\hline \multicolumn{10}{|c|}{ Years of employment in work area: } \\
\hline $1-9$ & 6 & 103 & (38 to 223 ) & 7 & 83 & (33 to 170 ) & 6 & 138 & (51 to 300 ) \\
\hline$\geqslant 10$ & 16 & 151 & (87 to 246 ) & 19 & 122 & (74 to 191 ) & 12 & 93 & (48 to 163 ) \\
\hline Total $(\geqslant 1 \mathrm{y})$ & 22 & 134 & (84 to 203 ) & 26 & 108 & (71 to 159 ) & 18 & 105 & (62 to 165 ) \\
\hline
\end{tabular}

pancreas (ICD 157), kidney (ICD 189), brain, and central nervous system (CNS) (ICD 191192), or from lymphoma (ICD 200-203) were not significantly increased in any of the six work areas. For these cancers cross stratification by work area and year of hire or years of employment in respective work areas did not show any results suggestive of an aetiological role of occupational risk factors. In the interest of brevity the stratified data for these cancer sites are not reported. Results for death due to cancer of two other sites previously associated with the rubber industry in some cohort studies, skin cancer, and thyroid cancer, are not included in table 1 because the overall number of deaths were too sparse and no excess was found among the entire cohort (skin cancer, ICD-9, 172-173, two deaths, SMR 29, 95\% CI 3 to 105 ; thyroid cancer, ICD 193, no deaths). Our findings for the remaining seven cancer 
Table 1 continued

\begin{tabular}{|c|c|c|c|c|c|c|c|c|}
\hline \multicolumn{3}{|c|}{ Storage, dispatch (IV) } & \multicolumn{3}{|c|}{ Maintenance (V) } & \multicolumn{3}{|c|}{ Others (VI) } \\
\hline Obs & $S M R$ & $(95 \% C I)$ & Obs & $S M R$ & $(95 \% C I)$ & Obs & $S M R$ & $(95 \% C I)$ \\
\hline 224 & 111 & (97 to 126 ) & 713 & 107 & (99 to 115 ) & 483 & 117 & (107 to 128$)$ \\
\hline 64 & 114 & (88 to 146 ) & 204 & 112 & (97 to 129 ) & 111 & 102 & (84 to 122$)$ \\
\hline 3 & 486 & (100 to 1419$)$ & 3 & 129 & ( 27 to 377 ) & 2 & 201 & ( 24 to 727 ) \\
\hline 3 & 229 & (47 to 670 ) & 6 & 133 & (49 to 290 ) & 4 & 174 & (47 to 446 ) \\
\hline 6 & 113 & (41 to 247 ) & 17 & 99 & (58 to 159 ) & 9 & 84 & (38 to 160 ) \\
\hline 5 & 110 & (36 to 256 ) & 12 & 82 & (42 to 143 ) & 9 & 98 & (45 to 187 ) \\
\hline 4 & 169 & (46 to 434 ) & 8 & 104 & (45 to 204 ) & 7 & 147 & (59 to 302 ) \\
\hline 2 & 96 & (12 to 347$)$ & 1 & 15 & & 2 & 50 & (6 to 181 ) \\
\hline 1 & 38 & & 2 & 24 & (3 to 86 ) & 4 & 81 & (22 to 207 ) \\
\hline 5 & 89 & (29 to 208 ) & 27 & 152 & (100 to 221 ) & 7 & 56 & (23 to 116 ) \\
\hline 6 & 253 & (93 to 551 ) & 12 & 159 & (82 to 279$)$ & 4 & 80 & (22 to 206 ) \\
\hline 2 & 105 & (13 to 380$)$ & 5 & 82 & (26 to 191 ) & 4 & 114 & ( 31 to 291 ) \\
\hline 0 & 0 & & 5 & 182 & (59 to 425 ) & 2 & 154 & (19 to 555$)$ \\
\hline 2 & 110 & (13 to 396$)$ & 4 & 70 & (19 to 178 ) & 1 & 28 & \\
\hline 3 & 182 & (38 to 532 ) & 6 & 114 & (42 to 249 ) & 6 & 178 & ( 65 to 387 ) \\
\hline
\end{tabular}

Table 2 continued

\begin{tabular}{|c|c|c|c|c|c|c|c|c|}
\hline \multicolumn{3}{|c|}{ Storage, dispatch (IV) } & \multicolumn{3}{|c|}{ Maintenance (V) } & \multicolumn{3}{|c|}{ Others (VI) } \\
\hline Obs & $S M R$ & $(95 \% C I)$ & Obs & $S M R$ & $(95 \% C I)$ & $\mathrm{Obs}$ & $S M R$ & $(95 \% C I)$ \\
\hline 1 & 506 & & 3 & 366 & (75 to 1069 ) & 0 & 0 & \\
\hline 2 & 567 & (69 to 2046 ) & 1 & 101 & & 2 & 359 & (44 to 1297 ) \\
\hline 0 & 0 & & 0 & 0 & & 0 & 0 & \\
\hline 1 & 369 & & 1 & 153 & & 1 & 179 & \\
\hline 2 & 577 & (70 to 2084 ) & 2 & 120 & (15 to 433 ) & 1 & 230 & \\
\hline 3 & 486 & (100 to 1419$)$ & 3 & 129 & (27 to 377 ) & 2 & 201 & (24 to 727 ) \\
\hline
\end{tabular}

Table 3 continued

\begin{tabular}{|c|c|c|c|c|c|c|c|c|}
\hline \multicolumn{3}{|c|}{ Storage, dispatch (IV) } & \multicolumn{3}{|c|}{ Maintenance (V) } & \multicolumn{3}{|c|}{ Others (VI) } \\
\hline Obs & $S M R$ & $(95 \% C I)$ & Obs & $S M R$ & $(95 \% C I)$ & $O b s$ & $S M R$ & $(95 \% C I)$ \\
\hline 1 & 301 & & 0 & 0 & & 0 & 0 & \\
\hline 2 & 288 & (35 to 1038 ) & 2 & 111 & (13 to 399$)$ & 3 & 276 & (57 to 806 ) \\
\hline 0 & 0 & & 4 & 238 & (65 to 608 ) & 2 & 186 & (23 to 670 ) \\
\hline 1 & 178 & & 2 & 159 & (19 to 575$)$ & 2 & 162 & (20 to 586 ) \\
\hline 2 & 268 & (32 to 966 ) & 4 & 123 & (33 to 315 ) & 2 & 188 & (23 to 679 ) \\
\hline 3 & 229 & (47 to 670 ) & 6 & 133 & (49 to 290 ) & 4 & 174 & (47 to 446 ) \\
\hline
\end{tabular}

Table 4 continued

\begin{tabular}{|c|c|c|c|c|c|c|c|c|}
\hline \multicolumn{3}{|c|}{ Storage, dispatch (IV) } & \multicolumn{3}{|c|}{ Maintenance (V) } & \multicolumn{3}{|c|}{ Others (VI) } \\
\hline Obs & $S M R$ & $(95 \% C I)$ & Obs & $S M R$ & $(95 \% C I)$ & Obs & $S M R$ & $(95 \% C I)$ \\
\hline 2 & 204 & ( 25 to 736 ) & 5 & 161 & (52 to 375 ) & 2 & 85 & (10 to 305$)$ \\
\hline 1 & 41 & & 4 & 68 & (18 to 174 ) & 3 & 78 & (16 to 227$)$ \\
\hline 5 & 228 & (74 to 532 ) & 9 & 104 & (47 to 197 ) & 5 & 88 & (28 to 205$)$ \\
\hline 4 & 181 & (49 to 464 ) & 6 & 124 & (46 to 271 ) & 8 & 147 & (63 to 289 ) \\
\hline 2 & 65 & (8 to 233 ) & 11 & 89 & (44 to 159 ) & 1 & 19 & \\
\hline 6 & 113 & (41 to 247 ) & 17 & 99 & (58 to 159 ) & 9 & 84 & (38 to 160$)$ \\
\hline
\end{tabular}

sites are presented by ICD and in context with our results cross stratified by work areas and time related factors.

MORTALITY FROM PHARYNGEAL CANCER

Mortality from pharyngeal cancer was increased in all six work areas (table 2), but was highest in work area IV (three deaths, SMR $486,95 \%$ CI 101 to 1419 ). All three deaths occurred among workers hired after 1950 and two were among those employed $\geqslant 10$ years in this work area (SMR 577). The moderately increased risks in work areas II and III were most pronounced among workers hired after 1960 and employed for $<10$ years in the respective work areas.

MORTALITY FROM OESOPHAGEAL CANCER

We found a significant increase in the mortality from oesophageal cancer in work area III (11 deaths, SMR 227, 95\% CI 114 to 407, table 3). Eight of the 11 cases had been employed for $\geqslant 10$ years in this work area (SMR 222, 95\% CI 96 to 438) and most workers who had died from oesophageal cancer were hired before 1960. Increased mortality from oesophageal cancer was also found among workers employed for more than one year in work areas IV, V, or VI. Yet, none of these results by work area and none of the results stratified by years of employment or year of hire were significant.

MORTALITY FROM STOMACH CANCER

The highest point estimate by work area for mortality from stomach cancer was found among workers who were employed in work area I (22 deaths, SMR 134, 95\% CI 84 to 203, table 4). Excess deaths occurred mainly among workers who had a long duration of employment in this work area (16 deaths, SMR 151, $95 \%$ CI 87 to 246 ) and among workers hired after 1950. However, none of these $95 \%$ CIs excluded the null value, possibly due to small numbers of deaths.

\section{MORTALITY FROM COLON CANCER}

We found an increased mortality from colon cancer in work area II (27 deaths, SMR 131, $95 \%$ CI 86 to 191, table 5). Stratification by duration of employment suggested that the risk was only increased among workers who were employed $\geqslant 10$ years in this work area (20 deaths, SMR 150, 95\% CI 91 to 231), whereas among workers employed for one to nine years the number of deaths was close to the expected value. Most of the excess deaths were attributable to workers who were hired before 1950 (15 deaths, SMR 164, 95\% CI 92 to 271 ).

\section{MORTALITY FROM PROSTATIC CANCER}

Mortality from prostatic cancer was increased in work area V (27 deaths, SMR 152, 95\% CI 99 to 221 , table 6 ). The excess was significant among workers hired before 1950 (18 deaths, SMR $172,95 \%$ CI 102 to 273). An increased risk was found in both strata of duration of employment, but no clear trend was found.

MORTALITY FROM BLADDER CANCER

The highest risk for bladder cancer was found among workers who had been employed for more than one year in work area IV (six deaths, SMR 253, 95\% CI 93 to 551, table 7). After further stratification by year of hire and by duration of employment in this work area, the highest SMRs were found among workers who had accumulated one to nine years of employment (five deaths, SMR 518, 95\% CI 168 to 1207) and among workers who were hired after 1960 (two deaths, SMR 506, 95\% CI 61 to 
Table 5 Cancer of the colon (ICD-153), observed deaths (obs) and SMRs (95\% CI) among male German rubber workers $(n=11663)$ 1981-91 by work area (I-VI), year of hire, and years of employment in work area (lagged by 10 years)

\begin{tabular}{|c|c|c|c|c|c|c|c|c|c|}
\hline & \multicolumn{3}{|c|}{ Preparation of materials (I) } & \multicolumn{3}{|c|}{ Technical rubber goods (II) } & \multicolumn{3}{|c|}{ Tyres (III) } \\
\hline & Obs & $S M R$ & $(95 \% C I)$ & Obs & $S M R$ & $(95 \% C I)$ & Obs & $S M R$ & $(95 \% C I)$ \\
\hline \multicolumn{10}{|l|}{ Year of hire: } \\
\hline$\geqslant 1960$ & 0 & 0 & & 5 & 137 & (44 to 318 ) & 2 & 86 & (10 to 309$)$ \\
\hline 1950-9 & 4 & 72 & (19 to 184$)$ & 7 & 83 & (33 to 170 ) & 4 & 75 & (20 to 191 ) \\
\hline$<1950$ & 9 & 138 & (63 to 262 ) & 15 & 164 & (92 to 271 ) & 5 & 68 & (22 to 158 ) \\
\hline \multicolumn{10}{|c|}{ Years of employment in work area: } \\
\hline $1-9$ & 6 & 121 & (44 to 264 ) & 7 & 97 & (39 to 200 ) & 3 & 81 & (17 to 237 ) \\
\hline$\geqslant 10$ & 7 & 77 & (31 to 159 ) & 20 & 150 & (91 to 231 ) & 8 & 72 & (31 to 142 ) \\
\hline Total $\geqslant 1 \mathrm{y}$ & 13 & 93 & (49 to 158 ) & 27 & 131 & (86 to 191 ) & 11 & 74 & (37 to 133 ) \\
\hline
\end{tabular}

Table 6 Cancer of the prostate (ICD-185), observed deaths (obs) and SMRs (95\% CI) among male German rubber workers ( $n=11663)$ 1981-91 by work area $(I-V I)$, year of hire, and years of employment in work area (lagged by 10 years)

\begin{tabular}{|c|c|c|c|c|c|c|c|c|c|}
\hline & \multicolumn{3}{|c|}{ Preparation of materials (I) } & \multicolumn{3}{|c|}{ Technical rubber goods (II) } & \multicolumn{3}{|c|}{ Tyres (III) } \\
\hline & $O b s$ & $S M R$ & $(95 \% C I)$ & Obs & $S M R$ & $(95 \% C I)$ & Obs & $S M R$ & $(95 \% C I)$ \\
\hline \multicolumn{10}{|l|}{ Year of hire: } \\
\hline$\geqslant 1960$ & 1 & 45 & & 2 & 64 & (8 to 230$)$ & 2 & 114 & (14 to 413 ) \\
\hline $1950-9$ & 9 & 154 & (70 to 292 ) & 7 & 89 & (35 to 183 ) & 7 & 148 & (59 to 305 ) \\
\hline$<1950$ & 11 & 118 & (59 to 212 ) & 13 & 100 & (53 to 172 ) & 13 & 124 & (66 to 211 ) \\
\hline \multicolumn{10}{|c|}{ Years of employment in work area: } \\
\hline $1-9$ & 7 & 118 & (47 to 243 ) & 9 & 107 & (49 to 204 ) & 5 & 120 & (39 to 281 ) \\
\hline$\geqslant 10$ & 13 & 117 & (62 to 199$)$ & 13 & 85 & (45 to 145 ) & 17 & 133 & (78 to 213 ) \\
\hline Total ( $\geqslant 1$ y) & 20 & 117 & (71 to 181 ) & 22 & 93 & (58 to 141 ) & 22 & 130 & (82 to 197 ) \\
\hline
\end{tabular}

Table 7 Cancer of the bladder (ICD-188), observed deaths (obs) and SMRs (95\% CI) among male German rubber workers ( $n=11663)$ 1981-91 by work area (I-VI), year of hire, and years of employment in work area (lagged by 10 years)

\begin{tabular}{|c|c|c|c|c|c|c|c|c|c|}
\hline & \multicolumn{3}{|c|}{ Preparation of materials (I) } & \multicolumn{3}{|c|}{ Technical rubber goods (II) } & \multicolumn{3}{|c|}{ Tyres (III) } \\
\hline & Obs & $S M R$ & $(95 \% C I)$ & Obs & $S M R$ & $(95 \% C I)$ & Obs & $S M R$ & $(95 \% C I)$ \\
\hline \multicolumn{10}{|l|}{ Year of hire: } \\
\hline$\geqslant 1960$ & 1 & 90 & & 2 & 126 & (15 to 455$)$ & 4 & 421 & (115 to 1078 ) \\
\hline $1950-9$ & 3 & 110 & (23 to 321$)$ & 4 & 102 & (28 to 261 ) & 2 & 82 & (10 to 297$)$ \\
\hline$<1950$ & 5 & 137 & (44 to 319 ) & 5 & 98 & (32 to 229 ) & 1 & 24 & \\
\hline \multicolumn{10}{|c|}{ Years of employment in work area: } \\
\hline $1-9$ & 2 & 78 & (10 to 282$)$ & 4 & 109 & (30 to 280 ) & 4 & 217 & (59 to 557 ) \\
\hline$\geqslant 10$ & 7 & 148 & (59 to 305 ) & 7 & 104 & (42 to 215 ) & 3 & 54 & (11 to 157 ) \\
\hline Total $(\geqslant 1 \mathrm{y})$ & 9 & 124 & (56 to 235 ) & 11 & 106 & (53 to 190$)$ & 7 & 94 & (38 to 194 ) \\
\hline
\end{tabular}

Table 8 Leukaemia (ICD-204-208), observed deaths (obs) and SMRs (95\% CI) among male German rubber workers $(n=11663)$ 1981-91 by work area (I-VI), year of hire, and years of employment in work area (lagged by 5 years)

\begin{tabular}{|c|c|c|c|c|c|c|c|c|c|}
\hline & \multicolumn{3}{|c|}{ Preparation of materials (I) } & \multicolumn{3}{|c|}{ Technical rubber goods (II) } & \multicolumn{3}{|c|}{ Tyres (III) } \\
\hline & Obs & $S M R$ & $(95 \% C I)$ & Obs & $S M R$ & $(95 \% C I)$ & Obs & $S M R$ & $(95 \% C I)$ \\
\hline \multicolumn{10}{|l|}{ Year of hire: } \\
\hline$\geqslant 1960$ & 1 & 109 & & 1 & 71 & & 0 & 0 & \\
\hline $1950-9$ & 7 & 360 & (144 to 741$)$ & 8 & 269 & (116 to 530$)$ & 0 & 0 & \\
\hline$<1950$ & 3 & 135 & (28 to 393 ) & 5 & 160 & (52 to 374 ) & 1 & 40 & \\
\hline \multicolumn{10}{|c|}{ Years of employment in work area: } \\
\hline $1-9$ & 1 & 58 & & 6 & 239 & (88 to 522$)$ & 1 & 80 & \\
\hline$\geqslant 10$ & 10 & 304 & (146 to 559$)$ & 8 & 163 & (70 to 322$)$ & 0 & 0 & \\
\hline Total $(\geqslant 1$ y) & 11 & 219 & (109 to 392$)$ & 14 & 189 & (103 to 317 ) & 1 & 19 & \\
\hline
\end{tabular}

1826). No increased risk was found among workers who were employed $\geqslant 10$ years in work area IV or who were hired before 1950. A similar pattern was found in work areas III and V. Although these data were sparse, some of the reported $95 \%$ CIs excluded the null value.

MORTALITY FROM LEUKAEMIA

Roughly twofold increases of mortality from leukaemia were found among workers employed at least one year in work areas I (11 deaths, SMR 219, 95\% CI 109 to 392) and II (14 deaths, SMR 189, 95\% CI 103 to 317, table 8). Excess deaths were also seen in work areas IV and VI. In all these work areas the excess deaths occurred mainly among workers hired between 1950 and 1959. Longer duration of employment was associated with a higher mortality from leukaemia among workers employed in work area I. Mortality from leukaemia was significantly increased among workers who had worked $\geqslant 10$ years in this work area (10 deaths, SMR 304, 95\% CI 146 to 559). No clear trend by duration of employment was found in work area II.

\section{Discussion}

Potential limitations of this study-such as underestimation or overestimation of risks due to the census type cohort study or potentially invalid comparisons of SMRs due to different age distributions of the compared populations - have been considered in a previous paper $^{1}$ and in part one of this report. ${ }^{2}$ Therefore, the focus of this discussion will rest on the interpretation of our findings in the 
Table 5 continued

\begin{tabular}{|c|c|c|c|c|c|c|c|c|}
\hline \multicolumn{3}{|c|}{ Storage, dispatch (IV) } & \multicolumn{3}{|c|}{ Maintenance (V) } & \multicolumn{3}{|c|}{ Others (VI) } \\
\hline Obs & $S M R$ & $(95 \% C I)$ & Obs & $S M R$ & $(95 \% C I)$ & Obs & $S M R$ & $(95 \% C I)$ \\
\hline 0 & 0 & & 1 & 37 & & 2 & 98 & (12 to 355$)$ \\
\hline 2 & 95 & (11 to 342 ) & 3 & 59 & (12 to 172 ) & 3 & 90 & (19 to 264 ) \\
\hline 3 & 162 & (33 to 474 ) & 9 & 124 & (57 to 236 ) & 4 & 83 & (23 to 214 ) \\
\hline 2 & 107 & (13 to 386$)$ & 7 & 172 & (69 to 355 ) & 4 & 86 & (23 to 219$)$ \\
\hline 3 & 112 & ( 23 to 327 ) & 5 & 47 & (15 to 110 ) & 5 & 112 & (36 to 260 ) \\
\hline 5 & 110 & (36 to 256 ) & 12 & 82 & (42 to 143 ) & 9 & 98 & (45 to 187 ) \\
\hline
\end{tabular}

Table 6 continued

\begin{tabular}{|c|c|c|c|c|c|c|c|c|}
\hline \multicolumn{3}{|c|}{ Storage, dispatch (IV) } & \multicolumn{3}{|c|}{ Maintenance (V) } & \multicolumn{3}{|c|}{ Others (VI) } \\
\hline Obs & $S M R$ & $(95 \% C I)$ & Obs & $S M R$ & $(95 \% C I)$ & Obs & $S M R$ & $(95 \% C I)$ \\
\hline 1 & 120 & & 5 & 218 & (70 to 507 ) & 2 & 83 & (10 to 298 ) \\
\hline 0 & 0 & & 4 & 76 & (20 to 195$)$ & 1 & 27 & \\
\hline 4 & 154 & (42 to 394 ) & 18 & 172 & (102 to 273 ) & 5 & 73 & (23 to 169 ) \\
\hline 4 & 181 & (49 to 464 ) & 9 & 185 & (85 to 352 ) & 4 & 65 & (17 to 166 ) \\
\hline 1 & 29 & & 18 & 139 & (82 to 220$)$ & 3 & 48 & (10 to 139 ) \\
\hline 5 & 89 & (29 to 208 ) & 27 & 152 & (100 to 221$)$ & 7 & 56 & (23 to 116 ) \\
\hline
\end{tabular}

Table 7 continued

\begin{tabular}{|c|c|c|c|c|c|c|c|c|}
\hline \multicolumn{3}{|c|}{ Storage, dispatch (IV) } & \multicolumn{3}{|c|}{ Maintenance (V) } & \multicolumn{3}{|c|}{ Others (VI) } \\
\hline Obs & $S M R$ & $(95 \% C I)$ & $O b s$ & $S M R$ & $(95 \% C I)$ & Obs & $S M R$ & $(95 \% C I)$ \\
\hline 2 & 506 & (61 to 1826 ) & 2 & 173 & (21 to 623 ) & 0 & 0 & \\
\hline 3 & 286 & (59 to 835$)$ & 4 & 163 & (44 to 417 ) & 0 & 0 & \\
\hline 1 & 97 & & 6 & 148 & ( 54 to 322 ) & 4 & 149 & (40 to 381 ) \\
\hline 5 & 518 & (168 to 1207 ) & 7 & 336 & (135 to 692 ) & 3 & 120 & (25 to 350 ) \\
\hline 1 & 71 & & 5 & 92 & (30 to 214 ) & 1 & 40 & \\
\hline 6 & 253 & (93 to 551 ) & 12 & 159 & (82 to 279 ) & 4 & 80 & (22 to 206 ) \\
\hline
\end{tabular}

Table 8 continued

\begin{tabular}{|c|c|c|c|c|c|c|c|c|}
\hline \multicolumn{3}{|c|}{ Storage, dispatch (IV) } & \multicolumn{3}{|c|}{ Maintenance (V) } & \multicolumn{3}{|c|}{ Others (VI) } \\
\hline Obs & $S M R$ & $(95 \% C I)$ & Obs & $S M R$ & $(95 \% C I)$ & Obs & $S M R$ & $(95 \% C I)$ \\
\hline 1 & 320 & & 1 & 96 & & 1 & 138 & \\
\hline 2 & 271 & (33 to 977 ) & 2 & 112 & (14 to 404 ) & 4 & 348 & (95 to 891 ) \\
\hline 0 & 0 & & 3 & 122 & ( 25 to 356 ) & 1 & 61 & \\
\hline 1 & 155 & & 2 & 149 & (18 to 539 ) & 3 & 172 & (35 to 502 ) \\
\hline 2 & 200 & ( 24 to 723 ) & 4 & 102 & (28 to 262 ) & 3 & 184 & (38 to 536 ) \\
\hline 3 & 182 & ( 38 to 532 ) & 6 & 114 & (42 to 249 ) & 6 & 178 & (65 to 387 ) \\
\hline
\end{tabular}

context of other epidemiological studies among workers employed in the rubber industry.

MORTALITY FROM PHARYNGEAL CANCER

Mortality from pharyngeal cancer was increased among our total cohort of active and retired male German rubber workers (SMR 144, 95\% CI 76 to 246 ). ${ }^{1}$ The analyses by work areas, presented in this paper, found increased SMRs in all six work areas. The highest increase was found in work area IV. Three other cohort studies on rubber workers provided results for cancers of the lip, oral cavity, and pharynx combined (ICD-9 140-149), but findings were inconclusive. ${ }^{6}$ Only one other study among rubber workers investigated specifically the risk of pharyngeal cancer and found significantly increased deaths among the entire cohort (SMR 149), ${ }^{5}$ but more detailed analyses identified no association with duration of employment in specific jobs. The fact that both studies which reported results specifically for pharyngeal cancer found an increased mortality deserves further attention. Based on our findings of an increased risk in work area IV, nitrosamines should perhaps be investigated further.

MORTALITY FROM OESOPHAGEAL CANCER

We found a slightly increased risk of oesophageal cancer among our total cohort of male German rubber workers. ${ }^{1}$ The analysis by work area showed a more than twofold increase in the mortality from oesophageal cancer in tyre production, and further stratification by time related factors was consistent with an aetiological role of occupational risk factors. Other cohort studies provided limited evidence of an excess mortality. Seven cohort studies ${ }^{6-13}$ found no increased mortality from oesophageal cancer. The cohort of the British Rubber Manufacturers Association (BRMA) ${ }^{5}{ }^{14}$ and a cohort study among Polish rubber workers ${ }^{15}$ found slightly increased risks (SMRs 114126). Subcohort analyses by work area of one study in the United States found increased mortality in reclaim workers but not in industrial product workers. ${ }^{16}{ }^{17}$ Among the BRMA cohort a significantly increased mortality in general rubber goods production (SMR 208) was found. ${ }^{14}$ The highest point estimate for oesophageal cancer in the rubber industry was found in a Scandinavian record linkage study among vulcanisation workers, mostly vulcanising patches in rubber repair situations (eight deaths, SMR 1008).$^{18}$ Thus, for entire cohorts and subcohorts or work areas no consistent picture emerged. Interestingly, recent studies from China suggest an association of dietary nitrosamines and oesophageal cancer, ${ }^{19}$ and our results by work area point to vulcanisation and thus possibly to nitrosamines as an occupational risk factor.

MORTALITY FROM STOMACH CANCER

In 1982 an IARC working group concluded that there was sufficient evidence for excess mortality from stomach cancer among workers employed in the rubber industry, and limited evidence for a causal association with compounding, mixing, and milling. ${ }^{3}$ Our results support this, as we found an increased risk in work area I, which was most pronounced among workers with longer duration of employment in this work area. Three other cohort studies published after the first evaluation by IARC in 1982 reported an excess occurrence of stomach cancer (SMR 110-142) 820 whereas seven cohort studies found no increased risks. However, all studies which investigated risks by work area found increased deaths in the weighing, mixing, and milling work areas (SMR 134-160) ${ }^{511}{ }^{21}$ including two studies which found less deaths than expected from stomach cancer for the entire cohort. ${ }^{1121}$ In other work areas, such as curing, reclaim, tubes, and industrial products, or after exposure to solvents no increased risks were 
found..$^{16}{ }^{17-23}$ In a nested case-control study risk factors for stomach cancer in the United States rubber industry were investigated by assessing exposure to nitrosamines, carbon black (suggestive results), detackifiers, and polycyclic aromatic hydrocarbons (PAHs) for 100 occupational titles. ${ }^{24}$ Exposure to detackifiers showed significantly increased risks, increasing with duration of employment and years since hire. Detackifiers were mainly identified as talc, and it was suggested that asbestos contamination might be the underlying cause. Thus, increased mortality from stomach cancer was still found in studies published after 1982, and the risk seems to be confined largely to mixing, milling, and compounding. Based on the current evidence, asbestos, talc, carbon black, nitrosamines, and heavy exposure to dusts should be considered for further analyses specific to exposures.

MORTALITY FROM COLON CANCER

Among our cohort the only substantially increased mortality from colon cancer was found in work area II. Further stratification by time related variables was suggestive of occupational risk factors. Before 1982 several studies from the United States had reported a small increase in risk of colon cancer among their entire cohorts. ${ }^{791025}$ Yet, no substantially increased risk was found in seven cohort studies or subcohort analyses published after the evaluation by IARC in $1982 .^{5811131622{ }^{26}}$ Since 1982, the only excess risk among an entire cohort was found among a cohort of Polish rubber workers (SMR 165) especially among production workers (11 cases, SMR=270). The risk was most pronounced in lacquering and product building (SMR 223) and mixing, milling, and vulcanisation (SMR 227). Excess risks among processing workers-that is, in compounding, mixing, milling and extrusionwere also found in a Swedish cohort ${ }^{11}$ and in job specific analyses of the early studies from the United States ${ }^{25} 2728$ Excess risks similar to our findings have only been reported by Baxter and Werner, who found an increased mortality from colon cancer in several subgroups of workers employed in the production of technical rubber goods. ${ }^{6}$ These findings and ours were not significant. Thus the overall evidence for excess mortality from colon cancer is still limited and the excess may be concentrated among workers in the early stages of production.

MORTALITY FROM PROSTATIC CANCER

Early studies in the United Kingdom found no increased mortality from prostatic cancer among their entire cohorts and only moderately increased risks based on few deaths in cables, electrical goods, and footwear. ${ }^{6}$ However, among United States rubber workers significantly increased risks were found in general service, ${ }^{28}$ maintenance, ${ }^{28} 29$ and janitoring or trucking, ${ }^{30}$ as well as compounding, mixing, and calendering. ${ }^{29}{ }^{30}$ Only one cohort study published since 1982 found an increased risk of prostatic cancer (SMR 518), although only based on two deaths. ${ }^{20}$ No substantially in- creased risks were found among five other cohorts $^{5811} 152026$ or subcohorts of reclaim and industrial product workers ${ }^{16} 17$ and weighers and mixers. ${ }^{11}$ Although our data are in agreement with these negative studies at the cohort level, our results by work area also corroborate the findings from the United States rubber industry of an increased risk of prostatic cancer in maintenance and general service. Furthermore, these results are supported by a recently published review, where it was concluded that repairmen were at increased risko of prostatic cancer. ${ }^{31}$ However, specific occupational risk factors for prostatic cancer remain largely unknown.

MORTALITY FROM BLADDER CANCER

Based on studies among British rubber workers the IARC working group concluded that there was sufficient evidence for excess mortality from cancer of the bladder. ${ }^{3}$ The risk was found among workers employed before 1950 in various work areas, mostly compounding and milling, that were linked to exposure to aromatic amines, especially $\beta$-naphthylamine and perhaps benzidine. ${ }^{6}{ }^{1432}{ }^{33}$ In cohort studies in the United Kingdom published after 1982 no further excess was found. ${ }^{53} 34$ Analyses of subcohorts of the United States studies (industrial products, curing, and reclaim) found non-significant SMRs between 130 and 230 (based on five to 21 cases). ${ }^{161722}$ As in an earlier publication, the excess was only found among workers hired before 1945. ${ }^{17}$ Studies from Italy, ${ }^{12} 20$ Sweden, ${ }^{11}{ }^{35}$ Norway, Poland, and Russia also found increased risks of bladder cancer (SMR $>140$ ) among the total cohort or in different departments. ${ }^{81526}$ Excess risks were found in mixing and milling, ${ }^{12}{ }^{15} 20$ tyre building, ${ }^{12} 26$ and various other departments. ${ }^{16} 17222635$ Thus epidemiological publications since 1982 corroborated the evidence for an increased mortality from bladder cancer among workers employed in the rubber industry. In our cohort an excess of bladder cancer was found among workers hired after 1960 (11 deaths, SMR 214, 95\% CI 107 to 384). ${ }^{1}$ To date these are the most reported deaths among workers hired after 1960. The highest point estimate was found in storage and dispatch, but a similar pattern was also noted in work area III. Other studies that presented risk estimates for workers hired after 1950 found an excess occurrence of bladder cancer among the entire cohort (based on one case) ${ }^{20}$ or based on two cases, among a subcohort of other workers. ${ }^{35}$ Further evidence for an excess risk of bladder cancer among rubber workers presumably not exposed to $ß$-naphthylamine came from a Canadian proportionate mortality study. Among workers of a rubber plant that never used $\beta$-naphthylamine, benzidine, 4-aminobiphenyl, or 4-nitrobiphenyl, an excess risk of bladder cancer was found (SPMR 128). ${ }^{36}$ In two epidemiological studies among workers who were employed at plants manufacturing chemicals, an excess of bladder cancer was associated with occupational exposure to $o$-toluidine and aniline $^{37}$ or arylamines other than benzidine or $\beta$-naphthylamine. ${ }^{38}$ Thus, aromatic amines other than $\beta$-naphthylamine or benzidine might 
be risk factors for bladder cancer in some subcohorts of rubber workers hired after 1950 . However, in our cohort, contamination of other aromatic amines by $\beta$-naphthylamine until the mid-60s might also account for at least part of the increased number of deaths. Finally, based on animal experiments and epidemiological studies in non-occupational settings, nitrosamines have been suspected of causing bladder cancer, and therefore warrant attention in further exposure specific analyses. ${ }^{19}$

\section{MORTALITY FROM LEUKAEMIA}

In 1982 the IARC working group concluded that there was sufficient evidence for excess mortality from leukaemia among workers employed in the rubber industry. Among a British cohort an excess of myeloid leukaemia was associated with one tyre plant where plastic film manufacturing entailed exposure to benzene. ${ }^{6}$ Similar Pliofilm production in the United States also resulted in exposure to benzene and excess mortality from myeloid leukaemia. $^{39}$ Yet, contrary to the British findings, the excess mortality from leukaemia in American rubber cohorts was most notably for lymphocytic leukaemia in various departments. ${ }^{27} 30{ }^{40}$ Nested case control studies of the American cohorts ${ }^{41}{ }^{42}$ elucidated that this excess was confined to one company, and investigating the same 10 to 15 cases it was concluded from further case-control studies that other solvents besides benzene might have played a causal part. ${ }^{23} 4344$ Subsequently, the excess risk for lymphocytic leukaemia in the American rubber industry was supported by two subcohort analyses. ${ }^{22} 45$ Except for the British BRMA study, ${ }^{5}$ we report here the largest number of cases of leukaemia among rubber workers since the last IARC evaluation. Our data suggest an association between mortality from leukaemia and occupational exposure in work areas I and II, where exposure to solvents may have been high. This association was most prominent among workers hired between 1950 and 1960. Since 1982 three cohort studies among rubber workers from other countries reported results for all haematological neoplasms combined (ICD-8 200-209 or ICD-9 200-208). ${ }^{81535}$ Only one cohort study presented specific results for myeloid leukaemia (ICD-8 205) and other leukaemias (ICD-8 207): Mortality from myeloid leukaemia was increased, but the result was based on only two cases. ${ }^{20}$ All other studies reported results for all leukaemias combined (ICD-8 204-207, or leukaemia). Four cohorts found no increased risk of leukaemia, but except from the BRMA study, ${ }^{5}$ the observed numbers of cases were small. ${ }^{11}{ }^{12} 46$ Work area specific analyses of two of these studies found no excess risk in weighing, mixing, ${ }^{11}$ or among workers exposed to dust, fumes, or solvents. ${ }^{5}$ Among rubber workers ${ }^{26}(\mathrm{SMR}=191)$ and vulcanisation workers ${ }^{18}$ an almost twofold excess was found in two Scandinavian studies. The excess among Norwegian rubber workers was discussed in association with exposure to a glue containing benzene. ${ }^{26}$ It is known that exposure to solvents in the rubber industry occurred mainly in parts of work area I (where solutions were made up) and in component assembly, ${ }^{3}$ the same work areas where excess mortality in our cohort study was found. However, no further evidence for causal associations with specific exposures, especially solvents, in the rubber industry was provided in studies published since 1982 and the question of leukaemia subtypes remained unsolved.

As for most other cohort studies on rubber workers, our results are stratified by work areas because information on exposure to specific carcinogens is currently not available. Furthermore, none of the studies on non-respiratory cancers among rubber workers discussed had sufficient information to control for smoking and alcohol habits, which are known risk factors and potential confounders for most of the cancer sites discussed. However, as indirect evidence, it may be of interest that two studies on risks of lung cancer in the rubber industry found no indication that the observed risks were confounded by smoking. ${ }^{13} 47$

\section{Conclusion and outlook}

Mortality from cancer of several sites was associated with employment in specific work areas, some of which have been associated in previous reports. Future analyses of our study will have to determine the role of specific exposures or exposure mixtures in the aetiology of these cancers. Nitrosamines have been discussed as risk factors for cancers at several sites found in excess in our cohort, including cancer of the oesophagus, pharynx, stomach, and bladder. Also, we attempted to include assessments of exposure to asbestos and talc, carbon black, solvents, and aromatic amines in a time, cost centre code, and plant specific job exposure matrix.

We thank the participating companies, the health insurance companies (Betriebskrankenkassen-BKK), the population registries, and the community health departments (especially Dr K Plentz and Professor P Volk) all of whom contributed tremendously during the data gathering phase of this study. Without their help this study could not have been completed. We are particularly grateful to Professor K Norpoth and Dr CA Veys for their continuing support and scientific advice throughout the study. Finally we acknowledge the important contributions to this study from field workers, programmers, and secretaries. The study was funded by the German Federal Ministry of Research and Technology, Bonn (Förderkennzeichen $01 \mathrm{HK} 470$ ), and was initiated, funded, and supported by the Berufsgenossenschaft der chemischen Industrie, Heidelberg.

1 Weiland SK, Mundt KA, Keil U, et al. Cancer mortality among workers in the German rubber industry: 1981-91. Occup Environ Med 1996;53:289-98.

2 Weiland SK, Straif K, Chambless L, et al. Workplace risk factors for cancer in the German rubber industry: part I: mortality from respiratory cancers. Occup Environ Med 1998;55:000-000.

3 International Agency for Research on Cancer. IARC monographs on the evaluation of the carcinogenic risk of chemicals to humans. Vol 28. The rubber industry. Lyons: IARC, 1982.

4 International Agency for Research on Cancer. IARC monographs on the evaluation of the carcinogenic risk of chemicals to humans, suppl 7: overall evaluations of carcinogenicity: an updating of IARC monographs. Vols 1-42. Lyons: IARC, 1987

5 Sorahan T, Parkes HG, Veys CA, et al. Mortality in the British rubber industry 1946-85. Br f Ind Med 1989;46:1-10. Baxter PJ, Werner JB. Mortality in the British rubber industries 1967-76. London: Her Majesty's Stationery Office, 1980.

Delzell E, Louik C, Lewis J, et al. Mortality and cancer morbidity among workers in the rubber tire industry. Am $\mathcal{F}$ Ind Med 1981;2:209-16.

8 Solionova LG, Smulevich VB. Mortality and cancer incidence in a cohort of rubber workers in Moscow. Scand incidence in a cohort of rubber workers Health 1993;19:96-101.

9 Andjelkovich D, Taulbee J, Symons M. Mortality experience of a cohort of rubber workers, 1964-73. F Occup Med 1976;18:387-94. 
10 Delzell E, Monson RR. Mortality among rubber workers. III. Cause-specific mortality, 1940-78. F Occup Med 1981; 23:677-84.

11 Gustavsson P, Hogstedt C, Holmberg B. Mortality and incidence of cancer among Swedish rubber workers, 1952-81. Scand $\mathcal{F}$ Work Environ Health 1986;12:538-44.

12 Negri E, Piolatto G, Pira E, et al. Cancer mortality in a northern Italian cohort of rubber workers [comments]. $\mathrm{Br}$ f Ind Med 1989;46:624-8.

13 Zhang ZF, Yu SZ, Li WX, et al. Smoking, occupational exposure to rubber, and lung cancer. $\mathrm{Br} \mathcal{F}$ Ind $\mathrm{Med}$ 1989;46:12-5.

14 Parkes HG, Veys CA, Waterhouse JA, et al. Cancer mortality in the British rubber industry. Brf Ind Med 1982;39:209-20.

15 Szeszenia-Dabrowska N, Wilczynska U, Kaczmarek T, et al. Cancer mortality among male workers in the Polish rubber industry. Pol f Occup Med 1991;4:149-57.

16 Delzell E, Monson RR. Mortality among rubber workers: X: reclaim workers. Am f Ind Med 1985;7:307-13.

17 Delzell E, Monson RR. Mortality among rubber workers: VIII: industrial products workers. Am $\mathcal{f}$ Ind Med 1984;6: 273-9.

18 Norell S, Ahlbom A, Lipping H, et al. Oesophageal cancer and vulcanisation work. Lancet 1983 ; i:462-3.

19 Bartsch H. N-nitroso compounds and human cancer: where do we stand? IARC Sci Publ 1991;105:1-10.

20 Bernardinelli L, de Marco R, Tinelli C. Cancer mortality in an Italian rubber factory. $\mathrm{Br} \mathcal{F}$ Ind Med 1987;44:187-91.

21 Wang HW, You XJ, Qu YH, et al. Investigation of cancer epidemiology and study of carcinogenic agents in the Shanghai rubber industry. Cancer Res 1984;44:3101-5.

22 Delzell E, Monson RR. Mortality among rubber workers: IX: curing workers. Am f Ind Med 1985;8:537-44.

23 Wilcosky TC, Checkoway H, Marshall EG, et al. Cancer mortality and solvent exposures in the rubber industry. $A m$ Ind Hyg Assoc 7 1984;45:809-11.

24 Blum S, Arp EW, Smith AH. Stomach cancer among rubber workers: an epidemiologic investigation. In: Lemen R,
Dement JM, eds. Dusts and diseases. Park Forest South, Ill: Dement JM, eds. Dusts and diseases.
Pathotox Publishers, 1979:325-34.

25 McMichael AJ, Spirtas R, Kupper LL. An epidemiologic study of mortality within a cohort of rubber workers, study of mortality within a cohort of

26 Norseth T, Andersen A, Giltvedt J. Cancer incidence in the rubber industry in Norway. Scand $\mathcal{F}$ Work Environ Health 1983;9(suppl 2):69-71

27 Delzell E, Monson RR. Mortality among rubber workers: V: processing workers. F Occup Med 1982;24:539-45.

28 Monson RR, Fine LJ. Cancer mortality and morbidity among rubber workers. F Natl Cancer Inst 1978;61:104753.

29 Goldsmith DF, Smith AH, McMichael AJ. A case-control study of prostate cancer within a cohort of rubber and tire workers. f Occup Med 1980;22:533-41.
30 McMichael AJ, Spirtas R, Gamble JF, et al. Mortality among rubber workers: Relationship to specific jobs. $\mathcal{F}$ Occup Med 1976;18:178-85.

31 van der Gulden JWJ. Metal workers and repairmen at risk for prostate cancer. Prostate 1997;30:107-16.

32 Veys CA. Two epidemiological inquiries into the incidence of bladder tumors in industrial workers. $\mathcal{F}$ Natl Cancer Inst 1969;43:219-26.

33 Veys CA. Bladder cancer in rubber workers: the story reviewed and updated. Plastics Rubber Process Applications 1981;1:207-12.

34 Sorahan T, Parkes HG, Veys CA, et al. Cancer mortality in the British rubber industry: 1946-80. $\mathrm{Br} \mathcal{F}$ Ind $\mathrm{Med}$ 1986;43:363-73.

35 Holmberg B, Westerholm P, Maasing R, et al. Retrospective cohort study of two plants in the Swedish rubber industry. Scand $\mathcal{f}$ Work Environ Health 1983;9(suppl 2):59-68.

36 Choi BC, Nethercott JR. A proportionate mortality study on risk of bladder cancer among rubber workers. Cancer Detect Prev 1991;15:403-6.

37 Ward E, Carpenter A, Markowitz S, et al. Excess number of bladder cancers in workers exposed to ortho-toluidine and aniline [comments]. F Natl Cancer Inst 1991;83:501-6.

38 Ouellet Hellstrom R, Rench JD. Bladder cancer incidence in arylamine workers. F Occup Environ Med 1996;38:1239-47.

39 Rinsky RA, Young RJ, Smith AB. Leukemia in benzene workers. Am f Ind Med 1981;2:217-45.

40 Andjelkovich D, Taulbee J, Symons M, et al. Mortality of rubber workers with reference to work experience. $\mathcal{F}$ Occup Med 1977;19:397-405.

41 McMichael AJ, Spirtas R, Kupper LL, et al. Solvent exposure and leukemia among rubber workers: an epidemiologic study. F Occup Med 1975;17:234-9.

42 Wolf $\mathrm{PH}$, Andjelkovich D, Smith A, et al. A case-control study of leukemia in the US rubber industry. $\mathcal{F}$ Occup Med 1981;23:103-8.

43 Arp EW Jr, Wolf PH, Checkoway H. Lymphocytic leukemia and exposures to benzene and other solvents in the rubber industry. F Occup Med 1983;25:598-602.

44 Checkoway $\mathrm{H}$, Wilcosky T, Wolf $\mathrm{P}$, et al. An evaluation of the associations of leukemia and rubber industry solvent exposures. Am F Ind Med 1984;5:239-49.

45 Delzell E, Monson RR. Mortality among rubber workers: VII: aerospace workers. Am f Ind Med 1984;6:265-71.

46 Carlo GL, Jablinske MR, Lee NL, et al. Reduced mortality among workers at a rubber plant. F Occup Med 1993;35: 611-6.

47 Andjelkovich DA, Abdelghany N, Mathew RM, et al. Lung cancer case-control study in a rubber manufacturing plant. Am f Ind Med 1988;14:559-74. 